\title{
Barium swallow study in routine clinical practice: a prospective study in patients with chronic cough ${ }^{*, * *}$
}

\author{
Estudo radiográfico com ingestão de bário na rotina clínica: \\ um estudo prospectivo em pacientes com tosse crônica
}

\author{
Carlos Shuler Nin, Edson Marchiori, Klaus Loureiro lrion, Artur de Oliveira Paludo, \\ Giordano Rafael Tronco Alves, Daniela Reis Hochhegger, Bruno Hochhegger
}

\begin{abstract}
Objective: To assess the routine use of barium swallow study in patients with chronic cough. Methods: Between October of 2011 and March of 2012, 95 consecutive patients submitted to chest X-ray due to chronic cough (duration $>8$ weeks) were included in the study. For study purposes, additional images were obtained immediately after the oral administration of $5 \mathrm{~mL}$ of a 5\% barium sulfate suspension. Two radiologists systematically evaluated all of the images in order to identify any pathological changes. Fisher's exact test and the chi-square test for categorical data were used in the comparisons. Results: The images taken immediately after barium swallow revealed significant pathological conditions that were potentially related to chronic cough in $12(12.6 \%)$ of the 95 patients. These conditions, which included diaphragmatic hiatal hernia, esophageal neoplasm, achalasia, esophageal diverticulum, and abnormal esophageal dilatation, were not detected on the images taken without contrast. After appropriate treatment, the symptoms disappeared in 11 (91.6\%) of the patients, whereas the treatment was ineffective in $1(8.4 \%)$. We observed no complications related to barium swallow, such as contrast aspiration. Conclusions: Barium swallow improved the detection of significant radiographic findings related to chronic cough in $11.5 \%$ of patients. These initial findings suggest that the routine use of barium swallow can significantly increase the sensitivity of chest X-rays in the detection of chronic cough-related etiologies.
\end{abstract}

Keywords: Barium sulfate; Cough; Contrast media; Radiography, thoracic.

\section{Resumo}

Objetivo: Investigar o uso rotineiro do estudo radiográfico com ingestão de bário em pacientes com tosse crônica. Métodos: Entre outubro de 2011 e março de 2012, 95 pacientes consecutivos submetidos a radiografia de tórax devido a tosse crônica (duração > 8 semanas) foram incluídos no estudo. Como propósito do estudo, radiografias de tórax adicionais foram obtidas imediatamente após a administração oral de $5 \mathrm{~mL}$ de uma suspensão de sulfato de bário a 5\%. Dois radiologistas avaliaram todas as imagens de forma sistemática para identificar alterações patológicas. 0 teste exato de Fisher e o teste do qui-quadrado para dados categóricos foram utilizados nas comparações. Resultados: As imagens obtidas imediatamente após a ingestão de bário revelaram patologias significativas potencialmente relacionadas a tosse crônica em 12 (12,6\%) dos 95 pacientes. Essas patologias, incluindo hérnia diafragmática, neoplasia de esôfago, acalasia, divertículo esofágico e dilatação anormal do esôfago, não foram detectadas nas imagens obtidas sem a administração do contraste. Após o tratamento adequado, os sintomas desapareceram em 11 pacientes $(91,6 \%)$, enquanto o tratamento foi ineficaz em 1 (8,4\%). Não foram observadas complicações relacionadas à ingestão de bário, como aspiração. Conclusões: A ingestão de bário melhorou a detecção de achados radiológicos significantes relacionados a tosse crônica em 11,5\% dos pacientes. Esses resultados iniciais sugerem que a utilização rotineira da ingestão de bário aumenta significantemente a sensibilidade de radiografias de tórax na detecção de etiologias relacionadas a tosse crônica.

Descritores: Sulfato de bário; Tosse; Meios de contraste; Radiografia torácica.

*Study carried out in the Laboratory of Medical Imaging Research, Santa Casa Hospital Complex in Porto Alegre/Federal University of Health Sciences of Porto Alegre, Porto Alegre, Brazil.

Correspondence to: Artur de Oliveira Paludo. Universidade Federal de Ciências da Saúde de Porto Alegre, Rua Sarmento Leite, 245, Moinhos de Vento, CEP 90050-170, Porto Alegre, RS, Brasil.

Tel. 5551 3303-9000. Fax: 5551 3303-8810.E-mail: arturpaludo@gmail.com

Financial support: None.

Submitted: 23 May 2013. Accepted, after review: 7 October 2013.

${ }^{* *}$ A versão completa em português deste artigo está disponível em www.jornaldepneumologia.com.br 


\section{Introduction}

Chest X-ray is performed widely as the firstchoice imaging modality for the investigation of thoracic complaints. ${ }^{(1)}$ The method is globally available and has been proven to be cost-effective in general practice. ${ }^{(1,2)}$ Frontal and lateral images are routinely acquired; however, some authors have contested the value of the lateral view in initial examinations, especially in patients under 40 years of age. ${ }^{(3)}$ Radiographic images provide a significant amount of valuable and sometimes vital information ${ }^{(1,4)}$ and thus have constituted the method of choice for the initial evaluation of patients for decades.

Barium sulfate is often used medically as a radiocontrast agent. It is prepared as an aqueous suspension and administered by enema or orally. Because it has a relatively high atomic number, its radiation absorption tends to be greater than that in other thoracic structures, providing better anatomic detail. ${ }^{(5)}$ Three types of barium studies can be performed, each requiring a different suspension preparation: barium swallow for the evaluation of the gastroesophageal junction, barium meal for the study of the antrum and duodenum, and barium follow-through for the assessment of the small bowel. ${ }^{(6)}$

The most common causes of chronic cough in adults are upper airway cough syndrome, asthma, and gastroesophageal reflux disease. ${ }^{(7,8)}$ The initial evaluation of a patient with chronic cough (duration $>8$ weeks) typically includes a focused history, physical examination, and chest $\mathrm{X}$-rays. These are firstly suggested in chronic cough because CT has a higher radiation dose exposure, higher costs, and a similar negative predictive value. ${ }^{(7,8)}$ To our knowledge, however, no study to date has investigated the benefits or drawbacks of the routine use of the barium swallow study in these patients. Therefore, the aim of our study was to assess the routine use of the barium swallow study in patients with chronic cough. We believe that the oral administration of barium enhances the evaluation not only of the esophagus and stomach but also of the heart chambers, great vessels, and airways. ${ }^{(9)}$

\section{Methods}

The institutional review board approved the study, which was conducted in accordance with the Declaration of Helsinki and Good Clinical
Practice guidelines (Protocol no. 221-12). All participants gave written informed consent before being included in the study. Between October of 2011 and March of 2012, 95 consecutive patients submitted to CXR due to chronic cough were included in the study. The inclusion criterion was a history of chronic cough with duration $>8$ weeks. All the patients underwent clinical examination and posteroanterior and lateral chest X-rays without the use of the oral barium sulfate suspension. These images were included in the control group.

For study purposes, additional posteroanterior and lateral images were obtained immediately after the oral administration of $5 \mathrm{~mL}$ of a $5 \%$ barium sulfate suspension (Bariogel; Cristália, São Paulo, Brazil). These images were included in the study group. The patients underwent both procedures on the same day. All of the radiographic images were acquired using a computed radiography system (CR 3110 Kodak Ektascan Storage Phosphor Reader; Kodak, Rochester, NY, USA) at a tube voltage of $125 \mathrm{kV}$ and $2.5 \mathrm{mAs}$. The radiation doses were $0.1 \mathrm{mSv}$ per examination.

Two thoracic radiologists with 12 and 7 years of experience, respectively, systematically evaluated the radiographic images from both groups in order to identify any pathological changes using a medical image displaying software (Advantage Workstation 4.4; GE Healthcare, Milwaukee, Wl, USA). The radiologists, who were blinded to the history of the patients, were allowed to change the window width and level and to use pan and zoom functions. The images taken after the oral barium administration were also examined carefully for any complications related to the contrast agent. When consensus was not reached, a third radiologist was consulted. The images taken with barium swallow were evaluated 7 days after the assessment of the control images using the same parameters.

True positive results were defined as the images in the study group that revealed a significant pathological condition potentially related to the chronic cough that responded to the treatment of that condition. False positive results were defined as the images in the study group that revealed a significant pathological condition potentially related to the chronic cough that was unresponsive to the treatment of that condition. No patients were excluded from the study. 
The analysis of the data collected was performed with the Statistical Analysis System, version 6 (SAS Institute, Cary, NC, USA). Fisher's exact test and the chi-square test for categorical data were used for the comparisons between the control and the study groups, and the level of significance was set at 5\% $(p<0.05)$.

\section{Results}

The study sample comprised 95 patients, with a mean age of 51.4 years (range, 15-88 years). Among these, 31 (32.6\%) were male and $64(67.4 \%)$ were female. Of the 95 patients, 23 were current or former smokers, with a mean smoking history of 10 pack-years (range, 1-20 pack-years).

In 12 patients (12.6\%), the images obtained with barium swallow revealed a significant pathological condition potentially related to chronic cough that was not detected on the images taken without contrast. These conditions included diaphragmatic hiatal hernia (confirmed by endoscopy), in 6 patients (5.2\%; Figure 1); esophageal neoplasm, in 1 (1.1\%; Figure 2); achalasia, in 2 (2.1\%); esophageal diverticulum, in 2 (2.1\%; Figure 3); and abnormal esophageal dilatation, in $1(1.05 \%)$, which was probably achalasia but unproven by endoscopy. Tertiary esophageal contractions and one case of a retroesophageal right subclavian artery (dysphagia lusoria) were observed only on the images after barium administration but were not recorded as pathological conditions. According to the literature, the majority of patients with these findings have no clinical signs or symptoms..$^{(8-10)}$ None of these patients were diagnosed with cancer or lung infection.
Among the 95 patients, a final diagnosis of pulmonary tuberculosis was made in 5 . The radiographic findings in these patients were not affected by barium swallow.

Patients with diaphragmatic hiatal hernias received antireflux therapy (omeprazole, antacid, and changes in lifestyle). Surgery was performed in the patients with esophageal neoplasm, achalasia, and esophageal diverticulum. The patient with abnormal esophageal dilatations also underwent surgical treatment. After appropriate treatment, the symptoms disappeared in $11(91.6 \%)$ of the 12 patients (Table 1). Antireflux therapy was ineffective in 1 patient with an esophageal hiatal hernia. In the cohort of 12 patients with a significant pathological condition detected with barium swallow, 4 were smokers, with a mean smoking history of 7 pack-years (range, 3-15 pack-years). Among the patients diagnosed with hiatal hernia on the X-ray, 1 had reflux-related symptoms and was part of the group in which antireflux therapy was effective. In addition, 1 patient diagnosed with achalasia retrospectively presented with dysphagia. The other 10 patients reported only chronic cough as a symptom. All of the comparisons in the study were statistically significant $(p<0.05)$.

No complications related to barium swallow, such as contrast aspiration, were observed. In addition, the procedure had no effect on the quality of the images.

\section{Discussion}

Chronic cough is a very common and nonspecific symptom of almost all chronic respiratory (and some non-respiratory) conditions. ${ }^{(7,8)}$ Clinical assessment, spirometry, and

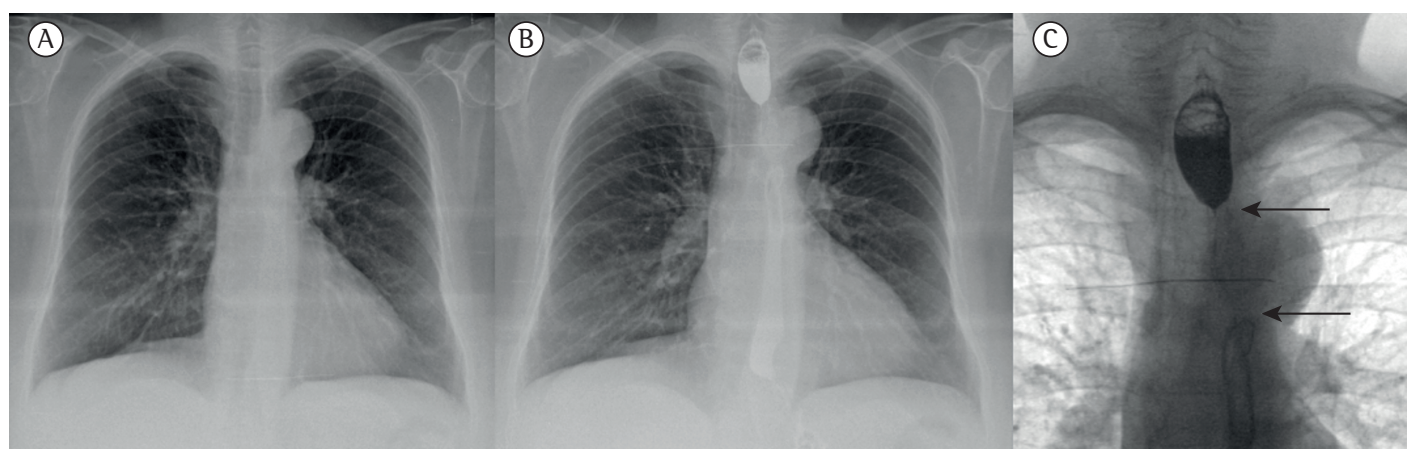

Figure 1 - Chest X-rays of a 61-year-old woman with a 3-month history of chronic cough. In A, posteroanterior chest $\mathrm{X}$-ray showing no significant alterations. In B and C, respectively, posteroanterior and lateral chest $X$-rays taken after barium swallow and showing the gastroesophageal junction (black arrow) above the esophageal hiatus of the diaphragm, consistent with hiatal hernia. 


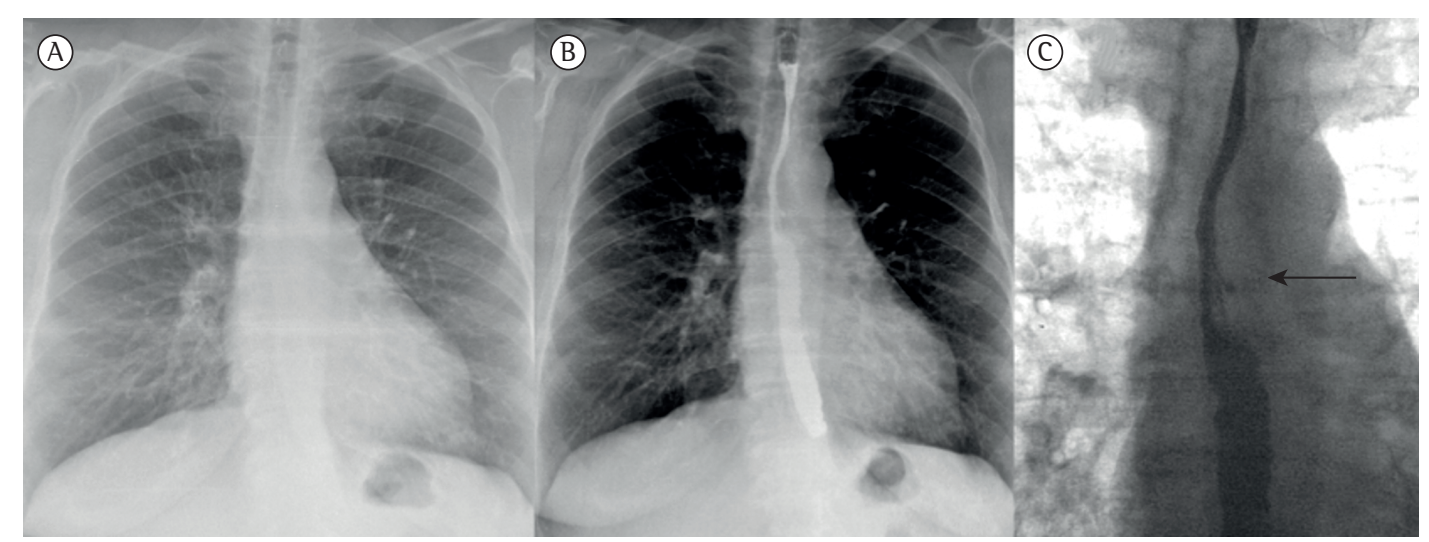

Figure 2 - Chest X-rays of a 65-year-old man with a 4-month history of chronic cough. In A, a posteroanterior chest X-ray showing no mediastinal alterations. In B and C, posteroanterior chest X-rays taken after barium swallow and showing an irregular area of narrowing (black arrows) that was subsequently diagnosed as esophageal cancer.

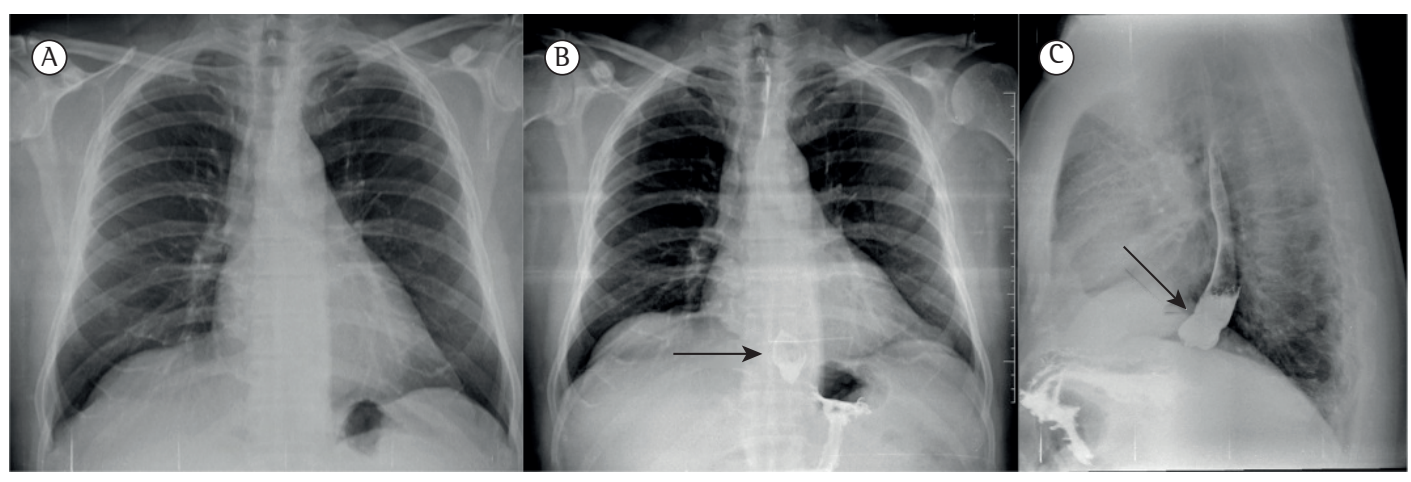

Figure 3 - Chest X-rays of a 47-year-old man with a 3-month history of chronic cough. In A, a posteroanterior chest X-ray showing no significant alterations. In B and C, chest X-rays taken after barium swallow and showing a diverticulum in the mid-esophagus (black arrow) that was diagnosed as a traction diverticulum caused by tubercular scarring in the perihilar lymph nodes.

Table 1 - Clinical characteristics of the 95 patients included in the study and diagnoses based on barium swallow studies.a

\begin{tabular}{lc}
\hline \multicolumn{1}{c}{ Characteristic } & Result \\
\hline Patients & 95 \\
Male gender & $31(32.6)$ \\
Smokers & $23(24.2)$ \\
Age, years & $52.4(15-88)^{\mathrm{b}}$ \\
Diagnosis & $11(11.5)$ \\
$\quad$ Diaphragmatic hiatal hernia & $6(5.2)$ \\
Achalasia & $2(2.1)$ \\
$\quad$ Esophageal diverticulum & $2(2.1)$ \\
Abnormal esophageal dilatation & $1(1.1)$ \\
Esophageal neoplasia & $1(1.1)$ \\
\hline
\end{tabular}

${ }^{a}$ Values expressed as $n(\%)$ of patients, except where otherwise indicated. ${ }^{b}$ Value expressed as median (range).

chest X-rays can readily detect various recognizable causes of chronic cough, such as COPD, chronic bronchitis, lung cancer, foreign body aspiration, pulmonary tuberculosis, sarcoidosis, idiopathic pulmonary fibrosis, and heart failure. ${ }^{(7,8)}$

From the opposite perspective, an extensive list of conditions can be suspected or confirmed with simple chest $\mathrm{X}$-rays. ${ }^{(1,7)}$ An evaluation of the respiratory system might reveal lung infiltration due to various pathologies, such as consolidations and neoplasms; parenchymal destruction; lymph node enlargement; pneumothorax; and pleural effusion. Cardiovascular imaging can reveal cardiomegaly, pericardial effusion, calcification foci causing atheromatosis, acute aortic syndromes, aneurysms, and congenital malformations. Bones, muscles, and breasts are also visible, enabling the diagnosis of numerous conditions, such as fractures, spinal diseases, and breast nodules. Groups of authors have indirectly reported that barium swallow studies enable the early diagnosis of various conditions, such as gastric and esophageal diseases, ${ }^{(10-19)}$ cardiovascular abnormalities, ${ }^{(20-23)}$ and even respiratory 
conditions, ${ }^{(24,25)}$ suggesting that the routine use of this method is justified and beneficial.

Our literature review found no studies evaluating the use of barium swallow studies in patients with chronic cough. Therefore, the parameters used in the present study were selected on the basis of those used in previous studies, $(4,9,14,16,24,25)$ taking into consideration the major anatomic relationships between the esophagus and other thoracic structures.

Barium aspiration is always a concern in the general practice. It is a well described and benign complication of barium swallow, although it is known to have harmful effects in the lung parenchyma. ${ }^{(26)}$ Fatal outcomes have been reported even after a low volume intake ${ }^{(27)}$ and after the use of low-dose barium suspensions. ${ }^{(27,28)}$ Although no consensus has been reached on the effects of barium sulfate administration in bronchographic studies, most authors have argued that simultaneous gastric content aspiration plays a greater role in causing parenchymal tissue reaction than does barium aspiration. In our study, no complications of this or any other nature were observed, which was probably related to the small study sample.

When considering the routine utilization of barium sulfate as contrast, the potential risk for false-positive findings, which could lead to unnecessary further examinations or interventions, is an important concern. The potential increase of the dose with the addition of this routine method was negligible. Few publications have reported information about overlooked conditions, such as gastric carcinoma and diaphragmatic hernia, which represent the most likely pitfalls of barium studies; however, these issues are related primarily to the barium meal technique. ${ }^{(29)}$ Since the X-ray is one of the most commonly performed imaging modalities, achieving greater sensitivity of the method and diagnostic accuracy for various diseases is perhaps a more important concern than is the potential risk for occasional false-positive diagnoses. In our study, only 1 patient (1.1\% of the study sample) had a false-positive diagnosis of hiatal hernia, since the chronic cough symptoms did not resolve after the treatment. In the present study, the response to treatment was the standard of truth employed in order to identify true-positive and false-positive findings were.

Our study has some limitations. First, the specificity of the proposed method was determined by the assumption that the lack of response to the treatment would mean that the chronic cough was motivated by another cause. In addition, we were unable to determine the sensitivity of the method. The diagnoses of esophageal cancer and esophageal diverticulum may represent a geographical bias, given the high incidence of tuberculosis (causing traction diverticula) and esophageal cancer in our region. ${ }^{(30)}$

In conclusion, the use of barium swallow improved the detection of significant radiographic findings related to chronic cough in $11.5 \%$ of patients. These initial findings suggest that the routine use of barium swallow can significantly increase the sensitivity of a widely available imaging modality. No complications associated with the procedure, such as contrast aspiration, were identified. However, further studies with a larger sample are necessary for the assessment of complication risks, false-positive findings, and the cost-effectiveness of this method before its use in daily practice can be securely recommended.

\section{References}

1. Speets AM, van der Graaf Y, Hoes AW, Kalmijn S, Sachs AP, Rutten $\mathrm{MJ}$, et al. Chest radiography in general practice: indications, diagnostic yield and consequences for patient management. Br J Gen Pract. 2006;56(529):574-8. PMid:16882374 PMCid:PMC1874520

2. Geitung JT, Skjaerstad LM, Göthlin JH. Clinical utility of chest roentgenograms. Eur Radiol. 1999;9(4):721-3. http://dx.doi.org/10.1007/s003300050741 PMid:10354893

3. Eisenberg RL, Hedgcock MW, Williams EA, Lyden BJ, Akin JR, Gooding GA, et al. Optimum radiographic examination for consideration of compensation awards: I. General methodology and application to chest examination. AJR Am J Roentgenol. 1980;135(5):1065-9. http://dx.doi. org/10.2214/ajr.135.5.1065 PMid:6778148

4. Gibbs JM, Chandrasekhar CA, Ferguson EC, Oldham SA. Lines and stripes: where did they go?--From conventional radiography to CT. Radiographics. 2007;27(1):33-48. http://dx.doi.org/10.1148/rg.271065073 PMid:17234997

5. Wiberg N, Holleman AF, Wiberg E, editors. Inorganic Chemistry. San Diego: Academic Press; 2001. p. 1044-342.

6. Kupershmidt M, Varma D. Radiological tests in investigations of atypical chest pain. Aust Fam Physician. 2006;35(5):282-7. PMid:16680204

7. Pavord ID, Chung KF. Management of chronic cough. Lancet. 2008;371(9621):1375-84. http://dx.doi. org/10.1016/S0140-6736(08)60596-6

8. Jacomelli M, Souza R, Pedreira Júnior WL. Abordagem diagnóstica da tosse crônica em pacientes não-tabagistas. J Pneumol. 2003;29(6):413-20. http://dx.doi.org/10.1590/ S0102-35862003000600016

9. Ugalde PA, Pereira ST, Araujo C. Correlative anatomy for the esophagus. Thorac Surg Clin. 2011;21(2):307-17, x. http://dx.doi.org/10.1016/j.thorsurg.2010.12.007 PMid:21477780 
10. Kahrilas PJ, Kim HC, Pandolfino JE. Approaches to the diagnosis and grading of hiatal hernia. Best Pract Res Clin Gastroenterol. 2008;22(4):601-16. http:// dx.doi.org/10.1016/j.bpg.2007.12.007 PMid:18656819 PMCid:PMC2548324

11. 11 Brazilian guidelines for the management of chronic cough [Article in Portuguese]. J Bras Pneumol. 2006;32(Suppl 6):S403-46. http://dx.doi.org/10.1590/ S1806-37132006001000002 PMid:17420904

12. Kostic SV, Rice TW, Baker ME, Decamp MM, Murthy SC, Rybicki LA, et al. Timed barium esophagogram: A simple physiologic assessment for achalasia. J Thorac Cardiovasc Surg. 2000;120(5):935-43. http://dx.doi. org/10.1067/mtc.2000.110463 PMid:11044320

13. Davies HA, Evans KT, Butler F, McKirdy H, Williams GT, Rhodes J. Diagnostic value of "bread-barium" swallow in patients with esophageal symptoms. Dig Dis Sci. 1983;28(12):1094-100. http://dx.doi.org/10.1007/ BF01295808 PMid:6653300

14. Campbell C, Levine MS, Rubesin SE, Laufer I, Redfern G, Katzka DA. Association between esophageal dysmotility and gastroesophaeal reflux on barium studies. Eur J Radiol. 2006;59(1):88-92. http://dx.doi.org/10.1016/j. ejrad.2006.02.002 PMid:16530370

15. Asghar M. Radiological investigation of dysphagia at D. H. Q. teaching hospital D. 1. Khan. J Ayub Med Coll Abbottabad. 2004;16(2):70-2. PMid:15455623

16. Levine MS, Rubesin SE, Ott DJ. Update on esophageal radiology. AJR Am J Roentgenol. 1990;155(5):933-41. http://dx.doi.org/10.2214/ajr.155.5.2120962 PMid:2120962

17. Aly YA. Digital radiography in the evaluation of oesophageal motility disorders. Clin Radiol. 2000;55(7):561-8. http:// dx.doi.org/10.1053/crad.1999.0509 PMid:10924382

18. Thomas PS, Carré 1J. Findings on barium swallow in younger siblings of children with hiatal hernia (partial thoracic stomach). J Pediatr Gastroenterol Nutr. 1991;12(2):174-7. http://dx.doi.org/10.1097/00005176199102000-00006 PMid:2051268

19. Soila P, Palmgren 0, Thomander K. The value of barium filling of the oesophagus in radiophotography (rp) of the chest. Acta Tuberc Pneumol Scand. 1964;45:1-13. PMid:14209267

20. Tonkin IL, Elliott LP, Bargeron LM Jr. Concomitant axial cineangiography and barium esophagography in the evaluation of vascular rings. Radiology. 1980;135(1):6976. PMid:7360983

21. Hogg K, Teece S. Best evidence topic report. The sensitivity of a normal chest radiograph in ruling out aortic dissection. Emerg Med J. 2004;21(2):199-200. PMid:14988349 PMCid:PMC1726310

22. Skinner LJ, Ryan S, Russell JD. Complete vascular ring detected by barium esophagography. Ear Nose Throat J. 2002;81(8):554-5. PMid:12199173

23. Burch M, Balaji S, Deanfield JE, Sullivan ID. Investigation of vascular compression of the trachea: the complementary roles of barium swallow and echocardiography. Arch Dis Child. 1993;68(2):171-6. http://dx.doi.org/10.1136/ adc.68.2.171 PMid:8481037 PMCid:PMC1029228

24. Gatewood OM, Vanhoutte JJ. The role of the barium swallow examination in evaluation of pediatric pneumonias. Am J Roentgenol Radium Ther Nucl Med. 1966;97(1):20310. http://dx.doi.org/10.2214/ajr.97.1.203

25. Baghdassarian OM, Gatewood WM. Barium swallow in evaluation of chronic or recurrent pneumonias in infancy and childhood. Md State Med J. 1965;14:51-6. PMid:14258949

26. Varatharaj A, Roome C, Allsup S. Barium aspiration. QJM. 2012;105(9):903-4. http://dx.doi.org/10.1093/ qjmed/hcr146 PMid:21865311

27. Buschmann C, Schulz F, Tsokos M. Fatal aspiration of barium sulfate. Forensic Sci Med Pathol. 2011;7(1):63-4. http://dx.doi.org/10.1007/s12024-010-9180-y PMid:20607457

28. Chiu CY, Wong KS, Tsai MH. Massive aspiration of barium sulfate during an upper gastrointestinal examination in a child with dysphagia. Int J Pediatr Otorhinolaryngol. 2005;69(4):541-4. http://dx.doi.org/10.1016/j. ijporl.2004.11.008 PMid:15763294

29. Shindoh N, Nakagawa T, Ozaki Y, Kyogoku S, Sumi Y, Katayama H. Overlooked gastric carcinoma: pitfalls in upper gastrointestinal radiology. Radiology. 2000;217(2):409-14. http://dx.doi.org/10.1148/radiology.217.2.r00oc29409 PMid:11058636

30. de Barros SG, Ghisolfi ES, Luz LP, Barlem GG, Vidal RM, Wolff FH, et al. High temperature "matè" infusion drinking in a population at risk for squamous cell carcinoma of the esophagus [Article in Portuguese]. Arq Gastroenterol. 2000;37(1):25-30. PMid:10962624

\section{About the authors}

\section{Carlos Shuler Nin}

Resident in Radiology. Santa Casa Hospital Complex in Porto Alegre, Porto Alegre, Brazil.

\section{Edson Marchiori}

Associate Professor of Radiology, Federal University of Rio de Janeiro, Rio de Janeiro, Brazil.

\section{Klaus Loureiro Irion}

Radiologist. Liverpool Heart and Chest Hospital NHS Foundation Trust, Liverpool, United Kingdom.

\section{Artur de Oliveira Paludo}

Medical Student. Federal University of Health Sciences of Porto Alegre, Porto Alegre, Brazil.

\section{Giordano Rafael Tronco Alves}

Medical Student. Federal University of Santa Maria, Santa Maria, Brazil.

\section{Daniela Reis Hochhegger}

Radiologist. Santa Casa Hospital Complex in Porto Alegre, Porto Alegre, Brazil.

\section{Bruno Hochhegger}

Thoracic Radiologist. Santa Casa Hospital Complex in Porto Alegre; and Professor of Radiology, Federal University of Health Sciences of Porto Alegre, Porto Alegre, Brazil. 